\title{
First City, Anti-City: \\ Cain, Heterotopia, and Study Abroad
}

\author{
Lance Kenney \\ Villanova University
}

The lament is a familiar one: the drive for internationalization, the end of education abroad's marginality, and increased demand for accountability in all of higher education draws attention to the lack of statistical analysis within study abroad. "Given the enthusiasm with which higher education institutions tout their study abroad programs, one might assume that a plethora of data exists to indicate that students reap significant academic and personal benefits from such experiences, but in fact the opposite is true" (Chieffo 165). In response, individual elements of the study abroad experience have been subject to quantitative research. Cross-/inter-cultural development, language acquisition, employment potential, and the impact of homestays, program duration, direct enrollment, even grading policies have been analyzed in the pages of Frontiers and other journals. This analysis more often than not utilizes methodologies particular to social science research (e.g., random sampling, pre- and post-tests, chi squares, Lichert scales). "Considered together, the growing body of study abroad research, especially studies carried out during the past decade, reveal the contours of a newly-emerging study abroad paradigm" (Vande Berg, xii).

What has been missing from the profession of education abroad is a parallel development of theory. While this abovementioned research has been invaluable for the field-especially in terms of legitimizing and positioning study abroad on campuses - the lack of more normative analysis is as much a shortcoming as the previous lack of empirical analysis. "(I)nternational educators have yet to embed their sentiments in a discourse with solid theoretical foundations that provides an alternative vision that is more in accord with both their own sentiments and the nature of the challenges faced by the people of the planet" (Skelly 22). The same legitimizing and positioning allowed by the quantitative can occur (especially for those based on university or college campuses) equally as well with the qualitative. 
A discussion of the city's relation to study abroad provides an opportunity to insert a theoretical element into the pedagogy of the profession. Specifically, I propose to introduce the Foucauldian concepts of "genealogy" and "heterotopia" to the idea of the "city," and in turn apply those same terms to the place of the city in the study abroad experience. Then, turning from Michel Foucault as "philosopher of space" to Paul Virilio, "philosopher of time," I will demonstrate the interplay between Foucault's heterotopia and Virilio's "anti-city," showing how study abroad in the contemporary, globalized city requires distinct programmatic changes to the (s)pace of education abroad.

\section{"That's all well and good in practice, but how does it work in theory?}

\section{Dr. Tad Waddington, Psychology Today}

Why should the field of overseas education care about theory? In a profession dominated by issues of health and safety, liability, pre- and postsojourn orientations, increasing participation rates and diversifying those participants, why should we bother with theory? Why should we spend time thinking when so much of our job is doing? And, given the many constraints within which the profession operates-again, the litany in the first sentence of this essay-isn't such activity merely sophistry?

The choice of the word "sophist" is deliberate, given its etymology. This dialectic between theory and practice, intellectualism and pragmatism, qualitative and quantitative schools of thought is a foundational one in Western Philosophy. The Western mileu (labeled by one author as everything from "Plato to NATO" [see Redhead]) has at its inception the variance between those think philosophy and theory are the best routes for rulers (Socrates, Plato) and self-rule (Aristotle) versus those that teach practical skills and techniques for success (the Sophists). From the outset, this philosophical divide is closely linked with politics, the former teaching statesmen to be visionaries, the latter teaching citizens to be effectual. This binary opposition continues throughout the Western philosophical tradition, perhaps best summarized by Kant when he derisively referred to "the old saw": "That May Be Right in Theory, But it Won't Work in Practice.” In other words, this divide between normative and empirical, though new to education abroad, is hardly new to higher learning. 
Therefore, to defend the role of theory in study abroad, two quotes spring to mind, one from a theorist outside the field, one from a practitioner within the field. In After Theory, Terry Eagleton states that theory is “.... reasonable systematic reflection on our guiding assumptions....(I)t comes about when we are forced into a new self-consciousness about what we are doing. It is a symptom of the fact that we can no longer take those practices for granted" (Eagleton, 2, 27). And from Josef Mestenhauser, in International Education: Towards a Critical Inquiry: "Unfortunately for the profession, there is some evidence of rising anti-intellectualism among [international educators]; a mere mention of a 'theory' often causes them to faint.....Although international education is meant to educate, few people have articulated the theoretical basis of its pedagogy" (Mestenhauser, $\mathrm{xx}$ ).

Taking Eagleton's definition and Mestenhauser's call for theory, we can then apply theory towards three broad purposes. First, theory allows the creation of normative judgments. Isaiah Berlin saw this capacity in politics when he wrote,

Among the many topics that remain obstinately philosophical, and have, despite repeated efforts, failed to transform themselves into sciences are some that in their very essence involve value judgments....When we ask what is perhaps the most fundamental of all political questions "Why should anyone obey anyone else?”...we are asking for the explanation of what is normative in such notions as authority, sovereignty, liberty... (qtd., $x x$ )

The same is true in study abroad. Without theory, we cannot ask the "fundamental" questions: What should our students be learning? What constitutes an "authentic" study abroad experience? What are the standards for a "good" program? These normative notions determine our goals as a profession, and should provide the framework for the ongoing research in our field.

Second (and by extension), theory provides the shared language for the profession. Though it is easy to draw a distinction between theory and activity-especially in a field that requires so much activity—it is theory that gives us our common vocabulary to promote action. One defender of political theory has written that "Robinson Crusoe on his desert island can do many things, but he cannot engage in politics." Our activities as a field require an interaction to promote certain common goals, and a shared 
professional language is necessary to meet those pragmatic goals. Buzzwords in the field that would benefit from a theoretical analysis might include internationalization, integration, immersion, competency, culture.

Finally, theory allows the determination of what qualifies as "study abroad." Theory is the basis for what French philosopher Lyotard called "narrative knowledge." A theoretical approach means that, taking the field of overseas education as a society of sorts, these theoretical narratives allow the profession to "define the criteria for competence," and to define according to those criteria "what is performed and what can be performed." To put it another way, in any sport, there is a rule book. Theory is the "rule book" for overseas education. "The rulebook only delimits the terrain in which... contingent strategies are shaped and enacted” (McGowan, 206).

\section{"Even for practical purposes theory generally turns out to be the most important thing in the end."}

Oliver Wendell Holmes

Before turning to a theoretical approach to the city and study abroad, the question arises, why is there no (or little) theory in international education? The answer can be found in another (similar) discipline, one with an equally strong theory/practice divide, international relations (IR). In 1966, theorist Martin Wight published the essay "Why Is There No International Theory?" Wight was part of the "English School" of scholars which presented itself as a "third way" in political theory between realism and idealism. As such, this school often found itself challenging basic definitions within political science and international relations. In this essay, Wight posits that though international relations as an academic area is an extension of political science, unlike political science there is no theory to support it as a discipline. "I believe it can be argued that international theory is marked, not only by paucity but also by intellectual and moral poverty" (Wight, $\mathrm{xx}$ ). He cites three broad reasons: IR's interdisciplinary nature; the supremacy of the nation-state within IR; and IR's underlying belief in linear progress.

Overseas education's "theoretical paucity" can be attributed to these same three categories. For instance, the profession's interdisciplinary status may be working against it in questions of theory. As Mestenhauser has argued, though we claim to be educators, do we fall within the traditional academic disciplines as teachers? Is there a single field from which we can 
pull our pedagogy? And if there is no agreement where study abroad falls academically, there is certainly no agreement on where overseas education falls administratively: Student Affairs? Student Services? Academic Affairs? Enrollment Management? Experiential Learning? The nebulous state of the profession surely hinders its ability to theorize.

Like International Relations, international education also remains statecentric, rarely distinguishing the qualitative differences of students that study in, say, Barcelona versus Bilbao. Open Doors numbers can indicate how many students study where; but a critical, theoretical approach would look past the labels of state boundaries to qualitatively, not quantitatively, analyze these numbers. As discussed by the University of Minnesota's Chip Peterson: "As we near the end of the 20th century, the gap between haves and have-nots is widening not only among countries but within them. This increasing polarization ought to be a central concern of international educators, but in fact it is seldom discussed" (Peterson, xx. Emphasis added).

Third, like the IR scholars whom Wight criticizes, international educators remain convinced of the notion of linear progress. The bulk of the work being done in outcomes assessment focuses on how students (prestudy abroad) are at point $\mathrm{A}$ and after their sojourn are at point B. Theory would first question the essence of point B. Can this teleology be a given? In the field of Student Development, research is based on holistic student learning over the course of four years. Can we effectively measure student outcomes based on perhaps one semester overseas? What are the assumptions that underpin our desire to measure outcomes in the first place? And can the non-linear schools of theory within other fields (say, post-structuralism in philosophy, the world history movement in history, cultural and literary theory generally) contribute anything to education abroad's concerns regarding student learning?

Eagleton writes that because most theory is critical self-reflection, "There is thus always something rather navel-starting and narcissistic about theory..." (Eagleton, 27). In the attempt to develop a theory for study abroad, this navel-staring needs to be avoided. Otherwise, as a profession, education abroad risks becoming like the Midgard Serpent in Norse mythology, a great snake with its own tail in its mouth. "Outside" theory needs to be mined, leading to such questions as, What theoretical frameworks can cognitive psychology share with education abroad to foster the student learning pro- 
cess? In what ways would pragmatism interpret how students construct meaning during their sojourn? How would a post-structuralist critique of globalization impact the development of new study centers? Where are the elements of feminism, postcolonialism, and development studies in predeparture and on-site orientations?

Walter Grunzweig has gone so far as to refer to a "crisis" in the field, brought on by developments in technology and contemporary criticisms of what Lyotard called the "grand narratives." The need for theory has become crucial as it is the only way to reflect on the "basic philosophy informing our activities," and find "new discourses that are appropriate to the new challenges" faced by international educators (Grunzweig, $\mathrm{xx}$ ). The theoretical city/study abroad juncture provides one such opportunity to address those challenges.

\section{"The form is fluid, but the 'meaning' is even more so." Frederick Nietzsche}

The city and the practice/profession of study abroad undoubtedly intersect historically. Chronologies of the field inevitably begin with the Henry James-esque "Great Cities" grand tours; highlight the first study centers established in European capitals after the Second World War; and perhaps end with statements like this journal's call for papers ("The majority of today's education abroad students will either study in a city or visit cities while learning abroad").

Equally important, the two are inextricably linked theoretically. Key concepts and concerns from urban studies easily apply to education abroad: the flow of bodies, the ordering of those bodies, the organization of space (spacialization), and the close association of space with "motion and time." Even a cursory reading of the annual Open Doors report will demonstrate our field's near-obsession with numbers of participants, destination, duration, etc.

An alternate approach to these abovementioned study abroad histories (and one of the few books in the field grounded in theory) is Joan Gore's Dominant Beliefs and Alternative Voices. Avoiding the teleological approaches of these other narratives, Gore instead outlines both an archaeology and a genealogy of the field, utilizing the works of French philosopher Michel Foucault. It is this second theoretical approach, genealogy, which will be of import here. "Let us give the term genealogy to the union of erudite knowledge and local memories which allows us to establish a historical knowledge 
of struggles and to make use of this knowledge tactically today....What it really does is to entertain the claims to attention of local...disqualified, illegitimate [emphasis added] knowledges against the claims of a unitary body of theory..." (Foucault Order xx). Or, to quote Gore, "Foucault labels this exploration of invalidated discourses 'geneaology'....(I)t raises the volume on alternative voices that have been excluded and hence unheard" (Gore, xx).

A second relevant (and lesser-known) Foucauldian theoretical model is that of heterotopia: those loci that 'dissolve our myths and sterilize the lyricism of our sentences" (Foucault, Order, xviii). To arrive at a definition of heterotopia that applies to study abroad, I will initiate a genealogy of the city by looking at the first city in the Judeo-Christian-Islamic tradition. Then, using this brief investigation to arrive at a definition of heterotopia, I will discuss the implication of heterotopia on study abroad programming.

\section{All by myself I have to go, With none to tell me what to do- All alone beside the streams And up the mountain-sides of dreams.}

\section{The strangest things are these for me, Both things to eat and things to see, And many frightening sights abroad}

\section{"The Land of Nod" Robert Louis Stevenson}

When looking for "disqualified," "illegitimate" sources, perhaps no figure in the Western tradition best meets these criteria than Cain. The oldest son of Adam, Cain kills his younger brother Abel out of jealousy after God finds favor with Abel's offering (the firstlings of his flock) over his own (fruit from the ground). After trying to hide the fratricide from God ("Am I my brother's keeper?"), Cain is banished from Eden, marked by God in such a way as that "no one who came upon him would kill him" (The Bible, Gen. IV:1-16).

This story is perhaps one the best known from Genesis, but the next few verses are relevant to this discussion. After settling in the land of Nod, east of Eden, Cain marries, has children, and builds the first city. Living with Cain in this first city are his descendants, some of whom are mentioned by name. They include Jabal, "the ancestor of those who live in tents and have livestock"; Jubal, "the ancestor of all those who play the lyre and the pipe"; 
and Tubal-cain, "who made all kinds of bronze and iron tools" (ibid, Gen IV: 17-22). In short, though Cain's sin forces him into exile, it is only within the city of which he is the progenitor that one sees the emergence of "civilization": agriculture, music, arts, and metalworking. Further, the root word for all three of his descendants' names, yabal, means "productive"; the "productive" element of Cain's ancestors (again, music, arts, and metalworking) further underscores the link between the first city and culture.

Besides these connections between this first city and culture, theologian Walter Brueggeman draws other connections that are more psychoanalytic. The important link for Brueggeman is not so much between Cain's lineage and this first city, but between the city itself and God's earlier warning to Cain: "If you do well, will you not be accepted? And if you do not do well, sin is lurking at the door; its desire is for you, but you must master it" (ibid, IV:7). This desire has Freudian psychoanalytic connotations for Cain and his descendents: "Freud has fully explored the relation between desire and culture. He has seen that on the one hand, there will be no culture unless desire is channeled and controlled." The point of the story may be to suggest that Cain and his family have begun to master this desire. "The 'mastery' leading to culture is never an untainted one; it brings together desire and control. Together they make the arts, city, and culture possible" (Brueggeman, $\mathrm{xx}$ ). To put it another way:

As Cain and his descendants experience an increasing fullness of life through a relationship with God (which is made implicit by the mark of protection Cain receives-God's love for the murdered is so profound that he is still blessed with divine protection), they experience the things a full life can offer. Their desire grows and, as Brueggemann points out, a culture which includes the arts as well as industry begins to emerge. Therein lies the place of the city. The city becomes the locus of the fullness of this life (Armentrout).

Order, control, desire: even in the first city one finds the themes evident in contemporary, critical urban studies. Given this city's origins with Cain and his exile from Eden, it is important to avoid a "city bad, country good" binary. The point is not to equate the city with the sin that prompted its creation. Instead, it is the ordering and control of that sin that is critical: the first city should not be equated with those later well-known cities, Sodom 
and Gomorrah! The first city finds among its defenders perhaps the most famous "theologian of the city," St. Augustine, who equates this first city with the "city of man" (contrasted with the "city of God"). However, "The things which this city desires cannot justly be said to be evil, for it is itself, in its own kind, better than all other human good." He continues, "These things [of Cain's earthly city: victory in war, peace, earthly goods], then, are good things, and without doubt the gifts of God" (St. Augustine, 481-482).

To rephrase, Cain has been forced from Eden, from paradise on Earth. He has been banished from a perfectly ordered, perfectly organized space. He has left behind a utopia. However, the space he then occupies is one where a relationship with God is still possible. (The chapter of Genesis ends with "At that time people began to invoke the name of the Lord," not distinguishing between Cain or his brother Seth's descendents). According to St. Augustine, it is still filled with the gifts of God. This "new" space east of Eden, this first city, is not inherently bad or evil. It is not the opposite of Eden, the opposite of utopia: it is NOT a dystopia.

At the 2005 conference for the Forum on Education Abroad, plenary speaker Andrei Codrescu remarked "In my day we had a different word for study abroad: exile." A poignant remark when looking at the parallels between Cain and study abroad. Cain leaves a "safe" space. He travels from the only home he has known to a new land, "Nod" (the translation of which is "wanderer"). He tries to achieve fullness of life in a new community. His new life becomes about order: ordering his passions, ordering his desires, ordering himself. And from this ordering he-or more importantly, his descendents - are able to tap into the basics of culture: art, music, and industry. As study abroad professionals, do we not try to do the same for our students? We encourage our students to leave home, to experience new communities, and to "order" themselves (use the host country language, internalize local social mores, continuously self-reflect). And, art, music and industry are forwarded as the best ways to achieve this intercultural ordering: museum trips in on-site orientations, podcasts as part of pre-departure programming, internships as a "must-have" at every overseas location.

Study abroad is no longer the "utopia" it once was-or perhaps it never was. The "big picture" of study abroad has changed radically in the past decade. More students than ever before are spending part of their undergraduate careers overseas, but the majority are going on short-term programs. The idea of "junior 
year abroad" has all but disappeared, to the point where only a few British universities still use the term "JYA." The sharp increase in overseas' university courses being taught in English (especially business schools in Western Europe) means that US students can take a full course-load in non-English speaking countries without learning the host language. And ubiquitous information technologies mean that students even while overseas are in touch with friends and family on a daily basis, never truly "disconnecting" from home.

However, if study abroad is no longer "utopic," it is certainly not a dystopia. "Cultural intelligence," "cross-cultural competence," "intercultural development," are all still desired and viable outcomes. Like Cain, like the profession of education abroad, our students exist in a space between utopia and dystopia. Acknowledging this other space, especially as it relates to students participating in city-based study abroad programs, can reshape the programmatic approach to the study abroad experience.

\section{The snake spoke truth; \\ it was the Tree of Knowledge; \\ It was the Tree of Life: \\ knowledge is good, \\ And Life is good; and how can both be evil?}

For Michel Foucault, this space of the "other" is best labeled as "heterotopia." These spaces are "...actual places, places that are designed into the very institution of society...in which the real emplacements, all the other real emplacements that can be found within the culture are, at the same time, represented, contested, and reversed, sorts of places that are outside all places, although they are actually localizable" (Foucault "Different Spaces" 178). These "other spaces" come in two types: "crisis" heterotopias (sacred spaces reserved for individuals in a state of crisis, e.g. menstruating women, old people) and "heterotopias of deviation" (spaces where people are put whose behavior is deviant with respect to the norm). Immediate examples of the latter include psychiatric hospitals, nursing homes, prisons, etc.

Heterotopias are better described by Foucault utilizing six basic principles (Foucault "Different Spaces" 180-184). First, though every culture probably has a heterotopia, there is not a single heterotopic form that is universal. 
Second, heterotopias can have multiple functions during its existence. Here Foucault points to the heterotopia of the cemetery, which moves from being a sacred space at the heart of the city to a marginalized space at the edges of the city simultaneous with the "secularization" of death in the $19^{\text {th }}$ century.

Third, the heterotopia "has the ability to juxtapose in a single real place several emplacements that are incompatible in themselves" (Foucault "Different Spaces" 181). Scene changes in theatres; cinematic three-dimensional images in two-dimensional space; and the microcosm of the zoological garden are all examples cited by Foucault. Fourth, heterotopias are heterochronias: they accumulate time as if it was a commodity (museums, libraries), or they consist of notime ("time in its most futile," e.g. carnivals, festivals, fairs, vacation villages, etc.).

Fifth, heterotopias are predicated on openings and closings, isolation and penetration, entrance and exclusion, all simultaneously. One is either constrained to enter, or gestures, rituals, and purifications are required for entrance. Barracks and prisons on the one hand, and Muslim baths and Scandinavian saunas on the other represent the two extremes of this type. Sixth and finally, heterotopias have a function in relation to the remaining space, either denouncing it as illusory (brothels) or treating it as something for which one must overcompensate ("absolutely perfect" colonies making "home" look even more disorganized).

Cain's city can be considered a heterotopia to Eden. Taking what little information we have from Genesis, it is easy to visualize this space as having multiple operations and sometimes incompatible emplacements; of functioning in regard to the existing space; of being a place of openness and isolation simultaneously. In short, it is an "other space" that is the different/opposite of the one that surrounds it. Or, to use another author's definition, if heterotopias "isolate deviant individuals...through the arrangement of space, technologies, and authorities” (Salter, 60), Cain can take credit for the first city and the first heterotopia.

And the relevance of heterotopia to study abroad? I believe the term has two important applications. One, I believe that we need to be conscious of the fact that as part of the study abroad trajectory, we subject students to a series of heterotopiae. Three are of specific importance.

Airport. First, there is the airport: "The trick of the modern airport is to present immobility as mobility, stagnancy as efficiency, and incarcerations as freedom" (Salter, 53). Airports are where people go to wait in order to leave; they 
are aligned with distant spaces rather than their local environment; they arrange people in a particular space that are in transit; local time is subservient to time at the potential destination; and, of course, "ritual" becomes an understatement in regards to the series of checks and inspections to which travelers are subjected. "The airport certainly qualifies as...heterotopia, both in terms of the isolation of the rites of passage of entry into and exit from the territory of the state, and in terms of the containment of deviant, mobile subjects" (Salter, 52).

Housing. A second heterotopia that constitutes the education abroad experience would be student accommodation. With few exceptions, students tend to live in three broad categories of housing: "ghettos" (in the historical, not socioeconomic sense of the word), properties purchased by program providers or US universities where all other residents are US undergraduates; apartment-style residences in close proximity to the host university (typically with other units occupied by young, urban professionals); or home-stays, an idealized attempt to replicate a "new" family for the duration of the sojourn. All of these spaces require students to occupy a place that makes them "deviant": they are living in situations that are unlike those of their undergraduate peers, something that is not the "norm" for their fellow students. Further, several "incompatible emplacements" are reflected in these accommodation types. The US dorm-a space of all Americans in one (foreign) place at the same time-is as anomalous as those other great heterotopiae, the prison and the hospital. Like the "extraordinary colonies of Jesuits" cited by Foucault, the apartment-style living arrangements are well-organized, absolutely regulated, and incongruous in that everything is provided for the students. And the motivation for their provision? More often than not, the desire to keep students from having long commutes. Finally, in home-stays, where a student tries to assume a place in a family without the time investment that is usually the basis for close relationships, is perhaps the ultimate heterochronia. Regardless, all three straddle that line between Foucault's last trait of the heterotopia: they maintain a relationship with the remaining space, but (like a brothel!) they are both a space of illusion AND a space that is "as perfect, as meticulous, as well-arranged as ours [the home culture] is disorganized, badly arranged, and muddled" (Foucault "Different Spaces" 184).

Academics. The third heterotopia that is "standard" for the study abroad experience would have to be the academic component. The accommodation triumvirate of US-student-only dorm, apartment-style living, and home-stay in regards to accommodation is analogous to the academic triple model of "island" 
program, study center, and customized academic program. Whether students are taking classes exclusively with other US undergraduates, courses specifically for US students offered by their host university, or customized classes offered by program providers, this "space" (albeit classroom space) is as heterotopic as the airport and the accommodation. These academic spaces once again are unlike the ones occupied by students' peers, but, to return to the original definition, they are an academic space where the local academics are "....represented, contested, and reversed, sorts of places that are outside all places, although they are actually localizable" (Foucault "Different Spaces" 178).

The point, again, is not to hearken back to an earlier utopist time in the history of education abroad. Students are not having a less "actual" experience by participating in these sorts of programs versus the sacrosanct times of direct enrollment, Junior Year Abroad, and "you're on your own for housing." Instead, by being conscious of these heterotopiae, we can better manage our expectations for student learning outcomes and, by extension, student expectations for the study abroad experience. "They offer no resolution or consolation, but disrupt and test our customary notions of ourselves” (Johnson, 87).

\section{Race de Caïn, ta besogne N'est pas faite suffisamment}

\section{Charles Baudelaire}

Highlighting education abroad as a series of heterotopic experiences is one application of Foucault's theoretical construct. A second application of heterotopia - and one that better lends itself to prescription-relates to study abroad in the contemporary, global city. When looking at those megapoli that tend to be the destinations of choice for our students (London, Tokyo, Buenos Aires, etc.) it may be that the modern city has become a heterotopia en toto. Take, for instance, the following statements, as reported by British nonprofit peopleandplanet.net:

- In 2008, half of the world's populations was urban. This number is projected by the United Nations to grow to $61 \%$ by 2030 .

- This projected growth in urban population represents a doubling of that population in developing nations.

- Africa and Asia are projected to have urban populations of $53 \%$ and $54 \%$ by 2030, whereas the Caribbean and Latin America will have urban populations approaching $84 \%$ (People and Planet). 
However, these migrations are occurring at the exact time that these cities are becoming "denationalized," stripped of the moorings that link them with the nation-state. Called "global cities" by scholar Saskia Sassen in Globalization and Its Discontents, these cities, used as "organizational commodities" by international firms, become nexii for the global economy, a "space [that] consists of airports, top-level business districts, top of the line hotels and restaurants-a sort of urban glamour zone, the new hyperspace of international business" (Sassen, 169). However, the workers attracted to the service jobs associated with this "glamour zone" come from these same migratory populations tracked by nonprofits like peopleandplanet.net. Further, many of these workers are "women, immigrants, and people of color, whose political sense of self and whose identities are not necessarily embedded in the 'nation' or the 'national community"' (Sassen, 162). The multinational corporations that inhabit the global city have no connection with the nation-state, and neither do its workforces or support staff.

Like a heterotopia, global cities are disconnected from the space around them, are spaces of openings and closings, are heterochronic ("the city that never sleeps"). For philosopher Paul Virilio, these global cities are anti-cities (Virilio Negative 100-104). The space between them, the space that connects them, has disappeared. The transportation and IT revolutions have made all activity within them transnational, not national. "If the metropolis is still a place...it no longer has anything to do with the classical oppositions of city/country nor center/periphery" (Virilio Lost 12). To put it another way, "Today, the transnational reduction affects each metropolis, each capital in both the East and the West; already they are nothing more than the place of a subaltern politics where each is almost imperceptibly losing its prerogatives" (Virilio Negative 96). Virilio's use of the word "subaltern" is critical here, especially given the term's importance to postcolonial literary theory. Sassen bears quoting again:

Cities are the terrain where people from many different countries are most likely to meet and a multiplicity of cultures come together. The international character of major cities lies not only in their telecommunication infrastructure and international firms, but also in the many different cultural environments they contain. One can no longer think of centers for international business and finance simply in terms of the corporate towers and corporate culture at their center. Today's 
global cities are in part the spaces of postcolonialism and indeed contain conditions for the formation of a postcolonial discourse (Sassen, 168).

Here, then, is the implication for study abroad and the theoretical construct of heterotopia (and, by extension, the anti-city). If the modern, global city is a heterotopia, how do we as educators bring this sort of critical analysis to our students' attention? How do we find ways to have our students interacting with those people that make up such large portions of these cities' population: the disadvantaged, the migratory, those with transnational identities? If these cities are merely massive terminuses, how do we approach questions of what Virilio calls "airport politics": who has the power? How does that power circulate? How does it impact identity formation? What has been the impact of transnationalism on local culture? In short, who are the subaltern in these global cities?

The case for postcolonialism has recently been made in the pages of Frontiers. However, this is just one theoretical approach for answering these questions. Post-structuralism, especially Foucault's concept of genealogy is only one other. The premise remains, however: as we reflect on questions of student learning, we must incorporate theoretical approaches to our programming in education abroad. If our students are indeed going to be studying primarily in cities, it is this sort of theoretical approach that will allow us to help them actually know those cities. One program provider's published statement that in cities like Florence, it is necessary to import Italians to run a "real" (authentic?) study program only accentuates this point. It is only through a theoretical lens that we can look at and define our concept of "authentic," and genuinely enhance the student experience.

\section{Works Cited}

Armentrout, Rev. James L. Private Correspondence, October 14, 2009.

Augustine of Hippo. The City of God. Introduction by Thomas Merton. New York: Random House: 2000.

The Bible, New Revised Standard Version. New York: Cambridge University Press, 1989.

Chieffo, Lisa and Lesa Griffiths. "Large-Scale Assessment of Student Attitudes After a Short-Term Study Abroad Program." Frontiers: The Interdisciplinary Journal of Study Abroad, 10. 
Brueggeman, Walter. Genesis: Interpretation: A Bible Commentary for Teaching and Preaching. Atlanta: John Knox Press, 1982.

Eagleton, Terry. After Theory. New York: Basic Books, 2003.

Foucault, Michel. "Different Spaces." Aesthetics, Method, and Epistemology:

The Essential Works of Foucault, 1954-1984, Volume II. James D. Faubion, editor. New York: The New Press, 1999.

---. The Order of Things: An Archaeology of the Human Sciences. New ork: Vintage Press, 1984.

Gore, Joan Elias. Dominant Beliefs and Alternative Voices: Discourse, Belief, and Gender in American Study Abroad. Florence: Routledge Press, 2005.

Johnson, Peter. "Unravelling Foucault's 'Different Spaces." History of the Human Sciences. Volume 19, number 4.

McGowan, John. Postmodernism and Its Critics. Ithaca: Cornell University Press, 1991.

Mestenhauser, Josef. "In Search of a Comprehensive Approach to International Education: A Systems Perspective" in Gruenzweig, Walter and Rinehart, Nana (Eds). Rockin' in Red Square: Critical Views of International Education in the Age of Cyberculture. Transaction/Rutgers University Press, New Brunswick: 2002. People and Planet. Retrieved at http://www.peopleandplanet.net/doc.php?id=1054\&section=5

Peterson, Chip. "Class and Study Abroad: Combining Concern and Compassion with Critical Analysis." Transitions Abroad. July/August 1997.

Redhead, Brian. Political Thought from Plato to NATO. London: BBC Books, 1984.

Salter, Mark B. "Governmentalities of an Airport: Heterotopia and Confession." International Political Sociology, Volume I, 2007.

Sassen, Saskia. "Excerpts from Globalization and Its Discontents," in The Blackwell City Reader. Malden, MA: Blackwell Publishing, 2002.

Skelly, James M. "Fostering Engagement: The Role of International Education in the Development of Global Civil Society." Retrieved from http://www.bcaabroad.org/peaceandjusticesig/home.html.

Vande Berg, Michael J., "Introduction." Frontiers: The Interdisciplinary Journal of Study Abroad, 10.

Virilio, Paul. Negative Horizon. New York: Continuum Books, 2006. ---. Lost Dimension. New York: Semiotext(e), 1984. 